Joanna Targońska

Uniwersytet Warminsko-Mazurski, Olsztyn

\title{
SŁABO ROZWINIĘTA KOMPETENCJA LEKSYKALNA DOROSEYCH - PRZYCZYNY, SKUTKI I MOŻLIWOŚCI JEJ POPRAWY
}

\begin{abstract}
The present paper attempts to investigate causes of poor lexical competence of prospective students of modern philology. The focus is placed on the techniques and cognitive strategies selected by such students in learning lexis.
\end{abstract}

\section{Wprowadzenie}

Dobrze rozwinięta kompetencja leksykalna jest podstawą opanowywania języka, bowiem umożliwia ona nie tylko recepcję, a więc pomaga w rozumieniu tekstów pisanych czy też słuchowych, ale warunkuje również umiejętność produkcji w języku obcym. Trudno jest bowiem sformułować jakikolwiek przekaz językowy bez posiadania zasobów leksykalnych. Niestety praktyka ostatnich lat pokazuje, iż mimo wielu lat nauki danego języka, oraz ogromnych możliwości jego przyswajania nie tylko podczas edukacji szkolnej, ale również poza nią (kursy, dostęp do nowoczesnych technologii, do tekstów obcojęzycznych w Internecie, komunikacja się na forach lub czatach internetowych), coraz gorzej przedstawiają się umiejętności językowe uczących się. Dużą rolę w niedostatecznie rozwiniętych sprawnościach zarówno receptywnych jak i produktywnych odgrywać może nieumiejętność uczenia się lub złe nawyki nabyte w trakcie nauki szkolnej.

Wprowadzenie nowej matury, a tym samym rezygnacja $z$ egzaminów wstępnych na studia, przyczyniły się do znaczących zmian w sylwetce kandydata na studia neofilologiczne. Mimo, że pojęcie autonomii, czy jak postuluje Wilczyńska (1999) półautonomii, funkcjonuje w dydaktyce języków obcych od wie- 
lu lat, a do wszelkiego rodzaju strategii przywiązuje się wielką wagę, dziwić może fakt, iż sylwetka abiturienta, a w naszym przypadku studenta podejmującego studia neofilologiczne, zamiast ulegać znaczącej poprawie, ulega znacznemu pogorszeniu. W czym można upatrywać takiego stanu rzeczy? Pierwszy kontakt ze świeżo upieczonymi maturzystami, czyli początkującymi germanistami, wykazał ich wielkie braki nie tylko w zakresie poprawności gramatycznej, ale wskazał na słaba, a w przypadku dość sporej grupy na bardzo słabo rozwiniętą lub wręcz nierozwiniętą kompetencję leksykalną, a co za tym idzie również kompetencję komunikacyjną. To skłoniło mnie do zastanowienia się nad przyczyną takiego stanu rzeczy. Możliwość regularnego kontaktu ze studentami pozwoliła mi na przeprowadzenie badań w działaniu, których celem (w niniejszym artykule skupimy się tylko na jednym z kilku zakładanych celów) było z jednej strony zbadanie kompetencji leksykalnej początkujących germanistów, z drugiej zaś strony znalezienie przyczyny takiego stanu rzeczy.

\section{Praca nad słownictwem jako przedmiot badań}

W niemieckojęzycznej literaturze glottodydaktycznej znajdziemy badania przeprowadzane na studentach oraz uczniach odnoszące się do ogólnie pojętej leksyki. Ponieważ niniejszy artykuł odnosi się do badania neofilologów, z tego też względu skoncentrujemy się tu na dwóch takich badaniach. Pierwsze z nich przeprowadzone przez Tschirner'a (2004) na studentach anglistyki i amerykanistyki, miało na celu uchwycenie stanu ich zasobów leksykalnych na początku studiów, tak aby możliwe było m. in. ustalenie ich przygotowania językowego do studiowania neofilologii w języku docelowym. Badanie wykazało, iż cele językowe zakładane w niemieckiej maturze z języka angielskiego (określające stan receptywnie opanowanej leksyki w na ok. 5000, a produktywnej na 4000 jednostek leksykalnych) zostały osiagnięte w przypadku słownictwa receptywnego jedynie przez $21 \%$, zaś w odniesieniu do produktywnie opanowanej leksyki tylko przez 2\% (zakładając, że wymagane jest 3000 jednostek leksykalnych) początkujących anglistów. Ponadto badanie wykazało brak korelacji między świadomą i celową nauką słownictwa a stanem zasobów leksykalnych, co wskazuje na fakt, iż osoby koncentrujące się na nauce słownictwa stosowały nieefektywne lub zbyt mało efektywne techniki. Z badań tych jasno więc wynika, iż większość studentów rozpoczyna studia anglistyczne $z$ brakami w zakładanych zasobach leksykalnych oraz bez wypracowanych efektywnych metod pracy nad słownictwem. Za jedną z przyczyn takiego stanu rzeczy Tschirner (2004: 126) uznaje brak konsekwentnej pracy nad słownictwem w szkole na wyższych poziomach zaawansowania. Z drugiej zaś strony stwierdza on, iż wprowadzanie strategii leksykalnych jak i ćwiczenia z nimi związane leżą jeszcze w powijakach.

Następnymi interesującymi nas badaniami były te przeprowadzone przez De Florio-Hansen $(2004,2006)$ na studentach różnych filologii i różnych kon- 
stelacji językowych ${ }^{1}$, których celem było zbadanie indywidualnej pracy studentów nad poszerzaniem zasobów leksykalnych w trakcie studiów. Badanie pilotażowe wykazało (populacja $n=72$ ), iż ponad połowa badanych stosuje nieefektywne strategie dotyczace utrwalania i poszerzania słownictwa. W badaniu głównym (n=339) cel został nieco zmieniony, bowiem badaczka chciała znaleźć przyczyny niezadowalającego poszerzania kompetencji leksykalnej w czasie studiów. Jej zdaniem przyczyną tą jest niewystarczające przekazywanie studiującym metod i możliwości indywidualnej pracy nad słownictwem. Badani wykazali się bowiem bardzo ogólną wiedzą na temat sposobów pracy nad słownictwem, brakowało im zaś wiedzy szczegółowej dotyczących technik i strategii, umiejętności przełożenia tego na własne strategie oraz umiejętności autonomicznego rozwijania swojej kompetencji leksykalnej, w związku z czym stosowali oni inne techniki niż te, które podawali jako zalecane.

\section{Czym jest kompetencja leksykalna?}

Wśród glottodydaktyków panuje jednomyślność na temat tego, iż kompetencja leksykalna jest niezbędnym czynnikiem warunkującym prawidłowe przyswajanie języka. Czym jest jednak kompetencja leksykalna? Niestety w tym względzie zdania są nieco podzielone, bowiem nie ma nawet jednomyślności w usytuowaniu tej kompetencji. Löschmann (1993: 142) traktuje kompetencję leksykalną jako składową kompetencji komunikacyjnej, natomiast w Europejskim Systemie Opisu Językowego (ESOJ) jest ona uważana za część kompetencji lingwistycznej.

Kilkanaście lat temu pojęcie kompetencji leksykalnej było nieco zawężone, bowiem Richards (1976 za Aguado 2004: 237) wymieniając elementy składające się na tę kompetencję koncentrował się na semantyce, morfologii, czy też elemencie syntaktycznym jako elemencie wiedzy (zapominając o elemencie stosowania wiedzy) uznając, że kompetencja leksykalna uczącego wyraża się tym, iż:

- zna on wartość semantyczną danej jednostki leksykalnej (dalej JL)

- zna różne znaczenie danej JL

- zna sieć skojarzeń istniejących między daną JL a innymi słowami

- zna granice użycia danej JL

- zna formy podstawowe oraz wyrazy pochodne

- zna zachowanie się syntaktyczne danej JL

- zna łączliwość leksykalną danej JL

Niestety w tym rozumieniu kompetencja leksykalna mogłaby być pojmowana jako wiedza deklaratywna, a przecież kompetencja powinna wyrażać przede wszystkim umiejętności. Pojęcie kompetencji leksykalnej powinno ujmować nie

\footnotetext{
1 Zarówno w badaniach pilotażowych (2004) jak i w badaniu głównym (2006) większość badanych studiowała angielski w połączeniu $z$ francuskim lub hiszpańskim, lub w innych konstelacjach. Wśród respondentów dominował więc angielski, a tuż za nim plasowały się francuski i hiszpański.
} 
tylko umiejętność rozumienia, lecz także aspekt prawidłowego zastosowania jednostek leksykalnych, adekwatnego do sytuacji, ale również z zachowaniem poprawności językowej (Aguado 2004: 237).

Z pewnością kompetencja leksykalna wyraża się również w tym, że uczący się potrafi pewnej formie wyrazu przyporządkować odpowiednie, konkretne w danej sytuacji znaczenie. Z drugiej zaś strony powinien on być w stanie dla uzyskania określonego znaczenia, nadać JL-nym odpowiednią formę. To wskazuje na to, iż w pojęciu kompetencji leksykalnej zawiera się niejako element gramatyczny. Wielu językoznawców wyraża przekonanie o nierozerwalności słownictwa i gramatyki, bowiem każda JL jest niejako „naznaczona” gramatycznie. Należy ona bowiem do odpowiedniej części mowy, występuje w określonych połączeniach syntagmatycznych lub paradygmatycznych, charakteryzuje się odpowiednią walencyjnościa, a wszystkie te elementy powinny być uwzględnione przy zastosowaniu danego słowa w zdaniu. Tak więc poprawne użycie słownictwa wymaga świadomego użycia wiedzy gramatycznej z nim związanej.

Pojęcie kompetencji leksykalnej powinno wyjść poza element deklaratywny oraz uwzględniać dostęp do wiedzy leksykalnej. Tak więc osoba charakteryzująca się kompetencją leksykalną nie tylko powinna być w stanie w odpowiednim momencie przywołać oraz poprawnie użyć daną JL, ale w przypadku „luki” w zasobach leksykalnych powinna ona potrafić skompensować swoje braki. Odnosi się to zarówno do recepcji, jak i produkcji (Można więc kompetencję leksykalna pojmować dwojako: jako kompetencję receptywną, lub jako kompetencję produktywna). Ważna tu będzie nie tylko znajomość słownictwa, ale również umiejętność jego zastosowania w odpowiednim momencie. Tak więc kompetencja leksykalna będzie wyrażała się z jednej strony w umiejętności dekodowania znaczenia danego słowa z kontekstu (przy uwzględnieniu słownictwa potencjalnego), z drugiej zaś strony w umiejętności obchodzenia się z niewystarczającymi zasobami leksykalnymi poprzez kreatywne wykorzystanie posiadanego słownictwa (Aguado 2004: 238, 247).

W kompetencji leksykalnej powinna się moim zdaniem zawierać także umiejętność kreatywnego wykorzystania własnych zasobów leksykalnych do kompensowania ich niedoskonałości jak i wielu luk we własnym słownictwie. Ponieważ dorośli uczący się powinni być w stanie dalej kierować swoim autonomicznym przyswajaniem języka, powinniśmy więc do tej kompetencji zaliczyć umiejętność pracy ze słownikiem nie tylko dwu-, ale również i jednojęzycznym. ${ }^{2}$

Zakładać można, iż osoba dorosła ucząca się już co najmniej 6 lat danego języka powinna charakteryzować się wysoko rozwiniętą kompetencją leksykalna. Jednakże, jak już wcześniej wspomniano, pierwszy kontakt ze świeżo upieczonymi studentami germanistyki wykazał (w przypadku większości z nich) ich bardzo ubogi zasób słownictwa, a co za tym idzie słabo rozwiniętą kompetencję

2 Więcej na temat postulowanego przez autorkę rozszerzonego pojęcia kompetencji leksykalnej - patrz Targońska (2011). 
leksykalna. Poznanie przyczyn takiego stanu rzeczy było punktem wyjścia do przeprowadzenia badań empirycznych. Wyszłam bowiem z założenia, iż tylko uchwycenie powodów leżących u podstaw niedostatecznych zasobów leksykalnych, może umożliwić podjęcie kroków mających na celu uzmysłowienie neofilologom ich błędów lub niedociagnięć w pracy własnej nad słownictwem oraz wskazanie drogi prowadzącej ku polepszeniu ich kompetencji leksykalnej.

\section{Wybrane elementy kompetencji leksykalnej początkujących neo- filologów - badanie empiryczne}

Niniejsze badanie, które zostało przeprowadzone w październiku 2010 r. na populacji 55 świeżo upieczonych studentów germanistyki na UWM w Olsztynie, miało na celu uchwycenia kompetencji leksykalnej początkujących germanistów ${ }^{3}$, przy czym skupimy się tu jedynie na dwóch jej elementach. Z jednej strony podjęta zostanie próba przedstawienia ogólnych technik uczenia się nowego słownictwa stosowanych przez badanych ze szczególnym uwzględnieniem nauki zachowania się syntaktycznego danej JL. Z drugiej zaś badaniu zostanie poddane stosowanie wybranych strategii kognitywnych w procesie internalizacji obcojęzycznych zasobów leksykalnych, co powinno pozwolić na znalezienie przyczyny słabo rozwiniętej kompetencji leksykalnej badanej grupy. Ze względów technicznych nie zostanie tu uwzględniona strefa użycia zasobów leksykalnych w sytuacjach komunikacyjnych (produkcja ustna oraz pisemna) oraz stosowanie strategii kompensacyjnych. Skupimy się więc jakoby na czynnikach warunkujacych zapamiętanie słownictwa, a tym samym stanowiących podstawę do rozwoju produktywnej kompetencji leksykalnej, pozostawiając poza kręgiem naszego zainteresowania czynniki warunkujące jego użycie, a więc strategie komunikacyjne, kompensacyjne, czy też strategie dyskursu.

\subsection{Opis narzędzia badawczego}

Narzędziem zastosowanym w niniejszym badaniu była ankieta (patrz aneks) składająca się z dwóch części. Pytania 1-2 stanowiły niejako metryczkę dotycząca samych badanych, gdzie uchwycono przebieg ich dotychczasowej nauki języka niemieckiego oraz usytuowanie przyswajania tegoż języka w całości kształcenia języ-

\footnotetext{
3 Wprawdzie badaniu została poddana określona grupa początkujących neofilologów z jednego kierunku na jednej uczelni, ale nie musi to oznaczać, że wyniki tu uzyskane odzwierciedlają tylko sytuację w tej grupie studiujących. Nie jest bowiem wykluczone, że pewna uchwycona tu sylwetka młodego abiturienta posiada znamiona charakterystyczne dla innych początkujących germanistów na innych uczelniach. Można spojrzeć na tę grupę badawczą jako na przekrój świeżo upieczonych abiturientów, bowiem w grupie badanej prawie każda osoba miała za sobą inną historię nauki języka niemieckiego, uczyła się w różnych szkołach, różnych miejscowościach oraz była „nauczana” przez różnych nauczycieli.
} 
kowego. Przedmiotem zainteresowania była również długość nauki języka niemieckiego ogółem oraz miejsca, w których taka nauka się odbywała. Kolejne pytania poświecone były już bezpośrednio dotychczasowej nauce nowych zasobów leksykalnych przez badanych, przy czym w pierwszej kolejności zostali oni poproszeni o określenie systematyczności swojej dotychczasowej nauki w domu oraz o subiektywną ocenę wyników samodzielnej pracy nad przyswajaniem leksyki. Kolejne pytania oznaczone numeracją I-III odnosiły się konkretnie do nauki słownictwa, gdzie zadaniem badanych było ustosunkowanie się do podanych zachowań uczeniowych oraz określenie ich częstotliwości. Pierwsza grupa pytań poświęcona była formie, w jakiej uczacy się przyswajaja nowe jednostki leksykalne. Ich celem było zbadanie, czy początkujący germaniści uczą się pojedynczych wyizolowanych słówek, czy też uczą się nowych rzeczowników oraz czasowników tak, aby byli oni w stanie użyć daną jednostkę leksykalną w każdej sytuacji (odmiana czasownika w różnych czasach, rodzajnik rzeczownika, liczba mnoga, uczenie się całych kolokacji, zachowania się walencyjnego itp.). Kolejnym interesującym zagadnieniem (patrz aneks - pytanie II) było poznanie stosowanych przez badanych metod mających na celu zapamiętanie nowego słownictwa. Zakładano tu również poznanie ewentualnego stosowania przez badanych kognitywnych strategii pamięciowych (patrz Bimmel/Rampillon 2000: 65). Innym z założeń niniejszego badania było uchwycenie zachowań badanych $\mathrm{w}$ momencie kontaktu $\mathrm{z}$ nieznanym słownictwem w tekstach pisanych (patrz aneks - pytanie III) oraz próba uchwycenia ewentualnego stosowania wybranych strategii kognitywnych, a mianowicie tych odnoszących się do przetwarzania języka ${ }^{4}$ (tamże). Za istotny czynnik w pracy nad słownictwem uznano bowiem umiejętność korzystania ze słownika, oraz samodzielne sterowanie poszerzaniem własnego słownictwa w kontakcie $\mathrm{z}$ tekstem pisanym zawierającym nieznane uczącemu się słownictwo. Czynniki te zostały właśnie uchwycone w pyt. III.

\subsection{Opis grupy badawczej}

Grupę badawczą stanowiły osoby dorosłe, które miały za sobą średnio ponad 8 lat nauki szkolnej lub pozaszkolnej języka niemieckiego. Ponad $65 \%$ badanych $(\mathrm{n}=36)$ uczyła się tego języka co najmniej 9 lat, ponad $20 \%$ badanych $(n=12)$ uczyło się go między 5 a 8 lat, a tylko blisko 1/10 uczyła się go poniżej 5 lat. Dla większości respondentów niemiecki był pierwszym językiem obcym, a tylko dla nieco powyżej $10 \%$ badanych $(n=7)$ stanowił on drugi język obcy (przy angielskim jako L2). Wszyscy z badanych uczyli się języka niemieckiego w szkole, ale tylko $14 \mathrm{z}$ nich ograniczało się jedynie do takiej nauki. Pozostali respondenci uzupełniali ją innymi formami edukacji. Budującym jest z pewnością fakt, iż ponad 1/3 (34,5\%) z nich miała okazję

\footnotetext{
4 Bimmel/Rampillon (2000: 65) zaliczaja do grupy kognitywnych strategii przetwarzania języka następujące grupy strategii: strukturyzacja, analizowanie oraz wykorzystywanie reguł, ćwiczenie oraz korzystanie z pomocy dydaktycznych (słowniki, repetytoria gramatyczne itd.)
} 
przebywać w kraju niemieckojęzycznym, z czego czworo badanych uczestniczyło w wymianie szkolnej z Niemcami. Niespełna 30\% miało okazję uczestniczenia w kółku języka niemieckiego, zaś blisko 23\% badanych uczęszczało dodatkowo na kursy języka niemieckiego i taka sama grupa korzystała z korepetycji.

Niestety nie wszyscy z badanych uczyli się przez ostatnie lata tego języka systematycznie, bowiem tylko w przypadku ponad połowy badanych $(\mathrm{n}=30)$ możemy mówić o regularnej pracy nad językiem, bowiem uczyli się go oni albo co najmniej raz w tyg., albo nawet po każdej lekcji $(n=11) .40 \%$ respondentów $(n=22)$ uczyło się języka niemieckiego tylko kilka razy w miesiącu lub wyłącznie przed zapowiedzianym sprawdzianem. W związku z tym nie może dziwić fakt, iż początkujący germaniści niezbyt dobrze oceniają skuteczność swojej dotychczasowej nauki słownictwa. Tylko dwoje z nich uznaje ją za bardzo wysoka, a 16 za wysoka. Oznacza to, że tylko 1/3 początkujących germanistów jest zadowolona ze swojej pracy nad zasobami leksykalnymi. Gros badanych ocenia swą skuteczność tak sobie $(n=33)$, nisko $(n=3)$ lub bardzo nisko $(n=1)$.

\subsection{Wyniki badań}

Analiza ankiety badawczej wskazuje na to, iż germaniści rozpoczynający studia wychodzą ze szkoły z bardzo złymi nawykami dotyczącymi pracy nad słownictwem, czy też brakiem wiedzy na ten temat, co należy uwzględnić w procesie przyswajania obcojęzycznej leksyki, co niewątpliwie może mieć przełożenie przede wszystkim na zapamiętanie, z drugiej zaś strony na nieumiejętność adekwatnego oraz poprawnego wykorzystania tych zasobów leksykalnych w komunikacji zarówno ustnej jak i pisemnej (słownictwo produktywne).

Słownictwo nie jest zbiorem pojedynczych „wyizolowanych” słówek, lecz stanowi ono system połączeń międzywyrazowych, które nie tylko ułatwiaja zapamiętywanie, ale również pozwalają na szybki dostęp do potrzebnych JL-ych w określonym momencie, jak i rozumienie nieznanych nam jeszcze słówek poprzez wykorzystanie mapy połączeń oraz skojarzeń z daną JL (Beile 1988: 5). Za negatywne przyzwyczajenie w uczeniu się leksyki należy więc uznać fakt pojmowania nauki słownictwa jako pracy nad pojedynczymi wyizolowanymi słówkami. Niestety blisko 80\% badanych (17 czyni tak zawsze, zaś 26 często) uczy się słówek właśnie w ten sposób (nauka pojedynczych słówek). Tylko czworo respondentów podaje, iż taką metodę stosuje rzadko lub nigdy, co może wskazywać na naukę jednostek leksykalnych w połączeniu (relacje syntagmatyczne lub paradygmatyczne). Takimi połączeniami mogą być niewątpliwie kolokacje ${ }^{5}$, dlatego

\footnotetext{
${ }^{5}$ Ponieważ uczącym się nie zawsze musi być znane nazewnictwo pewnych określeń językowych lub językoznawczych, słowo „kolokacje” nie zostało użyte w pytaniu skierowanym do badanych. W odniesieniu do metod i technik uczenia się nowych JL badani zostali poproszeni o określenie częstotliwości następującego zachowania „Przy nauce rzeczownika ucze sie czasownika, z którym on czesto wystęuje lub z którym można połaczyć dany rzeczownik".
} 
też podjęto tu również próbę sprawdzenia ewentualnego uczenia się kolokacji czasownikowych. Niestety jak wynika z odpowiedzi wskazanych przez germanistów, tylko 5 badanych często uczy się słownictwa w taki sposób, 13 badanych czyni tak czasami, zaś blisko $70 \%$ postępuje tak rzadko (n=25) lub nigdy $(n=12)^{6}$. Jest to potwierdzeniem wcześniej sformułowanej tezy, iż uczaç się zdają się nie widzieć potrzeby oraz wagi uczenia się wyrazów w połączeniach, czyli np. typowych kolokacjach. Podobnie rzecz się ma z nauką pewnych wyrażeń i fraz jako całości, choć w tym przypadku sytuacja zdaje się być nieco lepsza. Podobna liczba badanych podaje bowiem, iż uczy się jednostek leksykalnych w takim połączeniu bardzo często lub często $(30 \%)$, czasami $(35 \%)$ bądź też rzadko lub nigdy (ok. 35\%).

Do kolejnych złych nawyków w internalizacji leksyki języka obcego możemy zaliczyć fakt nauki nowych rzeczowników bez automatycznej nauki ich rodzaju7. Tylko 1/4 badanych uczy się nowych rzeczowników wraz z ich rodzajnikiem, a 32\% czyni tak często, zaś ponad 40\% respondentów uczy się ich w połączeniu z rodzajem tylko czasami, rzadko lub nigdy. Gorzej ma się sytuacja z nauką liczby mnogiej. Ponieważ w języku niemieckim liczba mnoga rzeczownika jest jakoby nowym leksemem (bowiem mnogość paradygmatów tworzenia liczby w dużej mierze uniemożliwia w bardzo wielu przypadkach samodzielne jej utworzenie), należałby w związku z tym uczyć się obok denotacji danego słówka jego rodzaju oraz liczby mnogiej. Niestety tylko trójka badanych czyni tak zawsze, natomiast 6 postępuje tak często. Pozostali początkujący germaniści uczą się liczby mnogiej czasami ( $n=19)$ oraz rzadko lub nigdy $(n=24)$. Tak więc blisko 80\% badanych wykazuje niewłaściwe nawyki w nauce języka niemieckiego niejako odbierając sobie szansę na poprawne wykorzystanie danego rzeczownika w liczbie mnogiej w sytuacji komunikacyjnej.

Negatywne zachowania uczeniowe dają się również zauważyć przy internalizacji czasowników. Ponieważ w języku niemieckim wiele czasowników charakteryzuje się nieregularną odmianą, polegającą najczęściej na zmianie samogłoski, wskazane byłoby przy nauce nowego czasownika sprawdzenie, czy w jego przypadku też dochodzi do nieregularności w koniugacji. Na taką specyfikę danego czasownika powinien wskazywać również wprowadzający go nauczyciel, tak aby uczeń od razu miał możliwość przyswojenia sobie poprawnej formy, a następnie jego poprawnego użycia, co nabiera z pewnością znaczenia na wyższych poziomach nauczania językowego. Takie nawyki powinni posiadać rów-

\footnotetext{
${ }^{6}$ Ponieważ jak wykazują badania przy wybieraniu spośród zamkniętej kafeterii odpowiedzi badani rzadko wybierają odpowiedzi skrajne, tak więc można by przypuszczać, że sporo osób zamiast wybrania odpowiedzi „nigdy” wybrało odpowiedź leżącą najbliżej niej, a więc „rzadko”.

7 Ponieważ w języku niemieckim deklinacja rzeczownika odbywa się poprzez odmianę rodzajnika przez przypadki (przy czym odmiana ta jest zależna od rodzaju rzeczownika), tak więc nieznajomość rodzaju danego słówka uniemożliwia wybór odpowiednie paradygmatu deklinacyjnego.
} 
nież przyszli germaniści, którzy w ramach studiów będą poznawali coraz więcej takich czasowników, a poza tym w dużej mierze sami powinni przejmować odpowiedzialność za autonomiczne poszerzanie słownictwa oraz poprawną internalizację jednostek leksykalnych. Niestety w tym przypadku dane nie są pocieszające, bowiem tylko nieco ponad $40 \%$ badanych zwraca przy nauce czasownika uwagę na jego odmianę (8 osób czyni bardzo często, zaś 16 często). Blisko $30 \%(n=16)$ czyni tak tylko czasami, a 13 rzadko lub nigdy.

Świeżo upieczeni germaniści, w większości po 9 latach nauki, niestety nie są równiė̇ jeszcze przyzwyczajeni do tego, aby przy nauce czasownika automatycznie nauczyć się jego form podstawowych, tak aby umieli oni użyć go nie tylko w czasie teraźniejszym, ale również i przeszłym, co jest szczególnie ważne przy umiejętności użycia danego czasownika, choć z pewnością może mieć niemałe znaczenie w procesie recepcji tekstów obcojęzycznych. ${ }^{8}$ Tak więc poprzez złe nawyki uczący się języka niemieckiego niejako odbierają sobie w przypadku nauki nowych czasowników nieregularnych możliwość poprawnego ich użycia, bowiem tylko 4 badanych podaje, iż zwraca przy ich nauce zawsze uwagę na formy podstawowe. Nieco ponad 20\% (n=12) czyni tak często, natomiast reszta badanych czyni tak albo czasami $(n=19)$, rzadko $(n=11)$ bądź nigdy $(n=5)$. Jakoby potwierdzeniem tych danych może być więc przyznanie przez $60 \%(n=33)$ badanych, iż w przypadku czasownika uczą się oni bardzo często lub często jedynie formy bezokolicznika, co może prowadzić do tego, iż nie będą oni potem w stanie zastosować go w komunikacji werbalnej.

Jak już powyżej nadmieniono, przedmiotem zainteresowania było również zbadanie, jakie strategie kognitywne związane w nauką nowego słownictwa stosowane są przez badanych. W badaniu daje się już na pierwszy rzut oka zauważyć stosowanie nieefektywnych metod mechanicznego uczenia się słownictwa, polegających na głośnym powtarzaniu nowych słówek (bardzo często i często czyni tak blisko 75\% ankietowanych) lub na kilkukrotnym ich powtarzaniu w myślach (czyni tak odpowiednio 76\%) ${ }^{9}$. Dziwić może jednakże fakt, iż jedna i ta sama osoba wskazywała na równie częste stosowanie jednej jak i drugiej techniki, co może wskazywać na brak świadomości uczeniowej (uczący się nawet nie pamięta, jak się uczy) lub na faktyczne stosowanie obydwu określanych jako nieefektywne technik uczenia się, bowiem uczeń może nie być do końca przekonany jaki styl poznawczy reprezentuje on i która z tych technik jest w jego przypadku „efektywniejsza”. Za jedyny pozytywny element w takiej nauce słówek może być uznany fakt, iż ponad połowa badanych w proces mechanicznego utrwalania słownictwa wkomponowuje element pisania. 11 badanych

\footnotetext{
8 Szczególnie nabiera to znaczenia w rozumieniu sprawozdań, w których bardzo często występuje czas przeszły Präteritum (stosunkowo rzadko stosowany w języku mówionym). 9 W pytaniu otwartym, w którym respondenci zostali poproszeni o wymienienie najczęściej stosowanych technik uczenia się, również podawane było w przeważającej większości to właśnie mechaniczne powtarzanie (wkuwanie) słówek.
} 
czyni tak bardzo często, zaś 19 często. Niestety blisko 1/3 badanych nie wykorzystuje sprawności pisania w procesie zapamiętywania leksyki.

Nieco lepiej wygląda sytuacja z wykorzystaniem myślenia skojarzeniowego w trakcie nauki nowego słownictwa, bowiem blisko $42 \%$ badanych przyznaje się do bardzo częstych lub częstych prób kojarzenia nowych słówek ze słówkami już im znanymi w tym języku (transfer wewnątrzjęzykowy), choć blisko 1/3 przyznaje, iż nie stosuje tej techniki nigdy, bądź czyni to bardzo rzadko. Tylko $27 \%$ przyznaje się do bardzo częstego lub częstego wykorzystania transferu interlingwalnego w nauce poprzez kojarzenie, natomiast 60\% nie wykorzystuje w nauce nowych jednostek leksykalnych asocjacji z podobnym słownictwem z innych języków. Ten fakt może nieco dziwić, bowiem zdecydowana większość badanych uczyła się języka angielskiego, którego zasoby leksykalne z pewnością dałoby się wkomponować w proces uczenia się słownictwa niemieckiego.

Kolejnym przykładem strategii kognitywnej, która mogłaby mieć zastosowanie w pracy nad internalizacją nowych zasobów leksykalnych jest porządkowanie i grupowanie wyrazów, czyli np. tworzenie grup wyrazów pasujacych do siebie pod różnym względem. Taka technika zdaje się być badanym również nieznana, albo nie są oni przekonani co do zasadności jest stosowania, bowiem tylko 12\% przyznaje się do jej stosowania ( 2 - bardzo często; 5 - często). Natomiast $67 \%$ albo stosuje ją rzadko $(n=22)$ bądź téz nigdy $(n=15)$. O braku aktywności podmiotu uczącego się w procesie nabywania nowej leksyki może świadczyć również fakt, iż tylko $20 \%$ badanych (3 - bardzo czyni tak często, a 9 - często) próbuje tworzyć zdania z nowym wyrazem bądź też zastosować nowa jednostkę leksykalną w nowych kontekstach ${ }^{10}$, natomiast ponad 41\% nie czyni tego nigdy, bądź czyni tak tylko bardzo rzadko. Nieznaną metodą nauki słówek zdaje się być katalog słówek, bowiem tylko jedna/en z badanych przyznaje się do ciagłego jej stosowania. 8 badanych stosuje go często, a 6 czasami. Niestety blisko $70 \%$ badanych nie stosuje tej metody nigdy, lub czyni to bardzo rzadko.

Analiza kolejnych czynników zawartych w części III ankiety, a więc tych dotyczących stosowania strategii kognitywnych odnoszących się do przetwarzania języka nie zostanie tu dokładnie przedstawiona, ze względu na ograniczenia miejsca, a będzie z pewnościa przedmiotem kolejnej rozprawy autorki. Pokrótce przedstawię tylko spostrzeżenia ogólne, które też rzucają negatywne światło na słabo rozwinięta kompetencję leksykalną początkujących germanistów. Okazuje się bowiem, że korzystanie ze słownika jednojęzycznego nie jest badanym prawie wcale znane (niespełna 15\% respondentów miało w ogóle kontakt z takim rodzajem słownika), co oznacza, że nie są oni przygotowani do pracy z nim na studiach. Blisko połowa badanych nie poszerzała do tej pory słownictwa we własnym zakresie np. w oparciu o przeczytany tekst (tzn. nie wypisywali oni nieznanych im słówek w celu ich późniejszego nauczenia się, czy też powtórze-

10 Nation (1990 za Aguado 2004) wychodzi z założenia, iż dana JL może być uznana za opanowaną gdy uczący się jest w stanie zastosować nowe słówko i nowym kontekście. 
nia). Prawie nigdy nie były wypisywane przez nich ciekawe zwroty, wyrażenia, czy tez wyrazy pokrewne. W przeważającej większości nie miało więc miejsca uczenie się incydentalne ${ }^{11}$. Analiza nieznanych słówek w czasie recepcji tekstów obcojęzycznych, poszukiwanie nieznanych leksemów należały również do rzadkości, bowiem tylko nieco ponad 1/4 badanych wykonywała kiedykolwiek taka czynność (4 bardzo często i 9 - często). Jedynym godnym odnotowania pozytywnym elementem jest podejmowana przez badanych próba zrozumienia znaczenia nieznanego słówka z kontekstu, bowiem blisko 75\% respondentów podało, iż w przypadku napotkania na nieznane im dotychczas słówko w czytanym przez nich tekście, najpierw próbowało zrozumieć jego znaczenie z kontekstu. (12 osób czyniło tak bardzo często, a 29 często)

\section{Uwagi końcowe}

Jak już wcześniej wspomniano, zdecydowana większość studentów rozpoczynających studia neofilologiczne (w tym przypadku germanistykę), przychodzi na studia ze słabo rozwiniętą kompetencją leksykalną. Kompetencja leksykalna zawiera w sobie element wiedzy deklaratywnej, czyli znajomość znaczenia jednostek leksykalnych; element umiejętności wyrażającej się w adekwatnym oraz poprawnym ich użyciu pod względem językowym, ale też stylistycznym czy też pragmatycznym; czy wreszcie element wiedzy proceduralnej pozwalający na komunikację w sytuacji niedostatecznych zasobów leksykalnych oraz wyrażającej się w umiejętnym „zarządzaniem" autonomiczną pracą nad poszerzaniem własnego słownictwa.

Jak pokazuja powyższe badania, świeżo upieczeni abiturienci, a więc w dydaktyce języków obcych traktowani jako uczące się osoby dorosłe, które powinny charakteryzować się działaniami autonomicznymi, nie tylko nie mają wypracowanych własnych metod nauki słownictwa, ale rozpoczynają studia językowe, nie dość że z ubogimi zasobami leksykalnymi, to również w wieloma negatywnymi nawykami dotyczącymi przyswajania leksyki. W ich nauce dominuje mechaniczna nauka wyizolowanych słówek (bez znajomości ich wartości gramatycznej, bez znajomości rodzaju, liczby mnogiej, walencyjności, czy tez zachowania syntaktycznego), co prowadzi po pierwsze do trudności z przywoływaniem danej JL z leksykonu mentalnego oraz powoduje, iż nie są oni w stanie poprawnie jej użyć zarówno w mowie jak i piśmie. Badani nie przejęli dotąd odpowiedzialności za poszerzanie własnego słownictwa (mając nadzieję, że samo kiedyś wejdzie do głowy), rzadko korzystają ze słownika, a jeżeli już po niego sięgna, to wypisuja z niego jedynie polski odpowiednik danego słówka. Ponadto w większości stosuja nieefektywne metody nauki słownictwa, nie łącząc ze sobą pojedynczych JL-ych w

\footnotetext{
11 Poprzez uczenie się incydentalne rozumiem takie uczenie, które dokonuje się niejako przy okazji pracy, której celem jest coś innego. Tak więc rozwiązując zadania na rozumienie tekstu czytanego można niejako „obok” czynności głównej, tj. czytanie ze zrozumieniem, nabyć nowe słownictwo.
} 
kolokacje, relacje syntagmatyczne, czy też paradygmatyczne. Nie może więc dziwić fakt, iż większość badanych swoją dotychczasową skuteczność nauki słownictwa ocenia nisko lub nawet bardzo nisko.

Co może być przyczyną takiego stanu rzeczy? Można by przypuszczać, że badani te negatywne nawyki wynieśli ze szkoły. Być może tam należy szukać źródeł przekonania, że nauka słownictwa jest nauką pojedynczych, wyizolowanych słówek, które należy „wykuć”. Często zachowanie uczącego się może wynikać jednakże z sytuacji lekcyjnej. W odniesieniu do nauczania szkolnego można wysnuć następujące wnioski. Testowanie pojedynczych słówek w postaci tłumaczenia może skłaniać uczących się właśnie do nauki jednostek leksykalnych w postaci dwujęzycznej listy. Natomiast wymaganie podania kolokacji (w sekwencjach ćwiczeniowych w ramach prowadzonych zajęć lekcyjnych, czy też na sprawdzianach) może mieć wpływ na takie właśnie uczenie się, w którym uczeń zwraca uwage na to, z czym dany wyraz można połaczyć, czyli np. na typowe kolokacje czasownikowe, które następnie mogą być łatwo wykorzystane w komunikacji werbalnej, kiedy to przekazujący komunikat potrafi niejako automatycznie przywołać do danego rzeczownika odpowiedni czasownik.

Nie bez wpływu na nawyki „obchodzenia się” z leksyką obcojęzyczną oraz na wypracowanie odpowiednich technik uczenia się jej, może być już samo wprowadzanie słownictwa oraz jego semantyzacja za zajęciach. Każda jednostka leksykalna składa się bowiem z kilku komponentów odnoszących się zarówno do formy (uczący się musi opanować komponent graficzny oraz fonetyczny) jak i do treści danego słówka (uczący się powinien poznać znaczenie danego słowa, oraz zostać wyposażonym w wiedzę na temat tego, kiedy może zostać ono użyte, czy jest ono z zakresu mowy potocznej, czy języka literackiego). Bardzo duże znaczenie ma tu również komponent kombinatoryczny (łączliwość leksykalna), który wskaże na to, czy dane słówko może zostać połączone z każdym innym dowolnym elementem leksykalnym, czy mamy tu do czynienia z określoną rekcja, kolokacją, czy té̇ związkiem idiomatycznym, albo frazeologicznym (patrz Bohn i Schreiter 2001; Scherfer 2007). Bohn (1999: 26) zwraca również uwagę na fakt, iż w każdą jednostkę leksykalną wkomponowany jest również komponent gramatyczny oraz słowotwórczy. Są to elementy łączace niejako formę z treścią. Tak więc już na etapie wprowadzania czy też semantyzacji słownictwa, nauczający może zwrócić uwagę uczącego się na wszystkie te elementy, a przez uświadomienie tych prawidłowości może jednocześnie wskazać mu droge dalszego postępowania w indywidualnej pracy nad przyswajaniem oraz poszerzaniem słownictwa.

Badanie wykazało, iż uczacy się wydają się nie znać podstawowych strategii kognitywnych umożliwiających nie tylko zapamiętywanie słownictwa, ale warunkujących taką internalizację, która będzie nie tylko długotrwała, ale umożliwi łatwe i szybkie przywołanie jednostki leksykalnej potrzebnej w danym momencie. Słownictwo powinno być przyswojone w takich połaczeniach, które pozwolą na poprawne jego użycie a jednocześnie na realizację sytuacji komunikacyjnych. W momencie internalizacji należy już zwracać uwage na aspekt użycia 
danej jednostki leksykalnej a nie tylko na umiejętność jej recepcji (Desselmann und Hellmich, 1986; Löschmann, 1993). W przypadku badanych można jednak odnieść wrażenie, że ich praca nad słownictwem na etapie nauki szkolnej była bardziej skoncentrowana na rozwijaniu słownictwa receptywnego bez uwzględnienia rozwijania słownictwa produktywnego ${ }^{12}$.

Cóż zatem robić, by nasi uczniowie lepiej przyswajali słownictwo i aby byli w stanie je później adekwatnie wykorzystać, aby nie mieli problemu z przywołaniem danego słówka w odpowiednim momencie ze swojego leksykonu mentalnego? Nauczyciele powinni przeanalizować organizowanie własnej pracy nad leksyką. Chodzi tu zarówno o ćwiczenia leksykalne, jak i o zadania komunikacyjne. Ponieważ w leksykonie mentalnym powinny powstać połączenia między relacjami paradygmatycznymi i syntagmatycznymi, w związku $z$ tym Bohn/Schreiter (2001: 189) postulują aby praca leksykalna zorientowana na relacje paradygmatyczne zawsze uwzględniała relacje syntagmatyczne.

$Z$ jednej strony nieodzownym wręcz elementem pracy nad słownictwem jest aktywizacja podmiotu uczącego, który musi podjąć wysiłek uczenia się i zaangażować się w rozwiązywanie zadania. A z tym wiąże się jego samodzielność (Bohn/Schreiter 2001: 190). Z drugiej zaś strony nowe jednostki leksykalne, które są wykorzystywane w sytuacjach komunikacyjnych, są lepiej i szybciej zapamiętywane, niż te, których uczymy się mechanicznie, które po prostu wkuwamy (Bohn/Schreiter 2001: 188). W związku z tym na lekcji w pracy nad słownictwem nie powinno się zapominać o ostatniej i jednocześnie najważniejszej fazie, a mianowicie fazie użycia. Uczącym należy przestawić lub zaproponować takie zadanie, w których będą oni niejako zmuszeni do wykorzystania nowo poznanych JL-ych w nowych, a jednocześnie ważnych dla nich sytuacjach komunikacyjnych.

Pewne wnioski nasuwaja się nie tylko w odniesieniu do głębszej analizy lekcji w szkole, ale również w odniesieniu do studentów neofilologów. Myślę, że dobrą praktyką jest zawsze poznanie sylwetki kandydata rozpoczynającego studia, aby można było już na początku jego kształcenia językowego poznać jego umiejętności, ale również doświadczenia i przekonania. Badania w działaniu oraz sama obserwacja może nam pokazać, że coś jest nie tak, że student postępuje źle. Jednakże poznanie źródła i przyczyn takiego stanu rzeczy pozwoli na pomoc studentowi na początku jego „,kariery studenckiej”, tak aby już na tym etapie studiów mógł on zweryfikować własne złe nawyki w nauce (w tym przypadku te dotyczace przyswajania słownictwa) i aby był w stanie przejąć odpowiedzialność za autonomiczny rozwój własnej kompetencji leksykalnej. Zdaniem De Florio-Hansen (2006: 182f) studenci neofilolodzy powinni być wspierani

\footnotetext{
12 Przyczyną takiego stanu rzeczy mogła być koncentracja na wypracowywaniu strategii egzaminacyjnych, ponieważ w egzaminie maturalnym większość punktów zdobywana jest za recepcję niż za produkcję. Takie przypuszczenia wysnuwał również Pawlak (2008: 155) badający stopień autonomiczności licealistów.
} 
przy poszukiwaniu własnych dróg i metod pracy nad słownictwem. Najlepiej uczynić to już na początku ich studiów.

\section{BIBLIOGRAFIA}

Aguado, K. 2004. „Evaluation fremdsprachlicher Wortschatzkompetenz: Funktionen, Prinzipien, Charakteristika, Desiderate". Fremdsprachen Lebren und Lernen 33: 231-250.

Beile, W. 1988. „Übungen und Üben im fremdsprachlichen Lernprozeß”. Der Fremdsprachliche Unterricht 92: 4-7.

Bimmel, P./Rampillon, U. 2000 Lernerantonomie und Lernstrategien. Berlin/München: Lanenscheidt

Bohn, R. 1999. Probleme der Wortschatzarbeit. Berlin: Langenscheidt.

Bohn, R./Schreiter, I. 2001.,Arbeit an lexikalischen Kenntnissen.” (w:) Einfïhrung in die Didaktik des Unterrichts Deutsch als Fremdsprache. Band I. (red. G Henrici i C. Riemer). Baltmannsweiler: Schneider Verlag: 166-201.

De Florio-Hansen, I. 2004. „Wortschatzerwerb und Wortschatzlernen von Fremdsprachenstudierenden. Erste Ergebnisse einer empirischen Untersuchung". Fremdsprachen Lebren und Lernen 33: 83-113.

De Florio-Hansen, I. 2006. „Vom Umgang mit Wörtern. Ergebnisse einer schriftlichen Befragung von Fremdsprachenstudierenden". (w:) Wortschatz. und Fremdsprachenlernen. (red. D. Siepmann) Verlag Empirische Pädagogik: Landau: 145-191.

Desselman, G. i Hellmich, H. 1986. Didaktik des Fremdsprachenunterrichts (Deutsch als Fremdsprache). Leipzig: Verlag Enzyklopädie.

Nation, I. S. P., 1990. Teaching \& Learning Vocabulary. New York: Newbury House.

Löschmann, M. 1993. Effiziente Wortschatzarbeit. Alte und neue Wege. Frankfurt am Main: Peter Lang.

Pawlak, M. 2008. „Autonomia w nauce języka angielskiego w liceum - diagnoza, analiza, wnioski". (w:) Autonomia w nauce jesylka obcego - co osiagnelismy i dokad zmierzamy. (red. M. Pawlak). Wydawnictwo Państwowej Wyższej Szkoły Zawodowej: Konin: 137-157.

Richards, J.-C. 1976. „The role of vocabulary teaching”. TESOL Quarterly 10. 77-89. Scherfer, P. 2007. „Wortschatzübungen”, (w:) Handbuch Fremdsprachenunterricht. 5. wyd. (red. K.-R., Bausch, H. Christ, i H.-J. Krumm) Tübingen und Basel: Francke: 280-283.

Targońska, J. 2011. „Lexikalische Kompetenz. Ein Plädoyer für eine breitere Auffassung des Begriffs". Glottodidactica XXXVII: 117-127.

Tschirner, E. 2004. „Der Wortschatzstand von Studierenden zu Beginn ihres Anglistikstudiums." Fremdsprachen Lehren und Lernen, 33: 114-127.

Wilczyńska, W. 1999. Uczyć sie być nauczanym? O autonomii w prayswajaniu jezykea obcego. Warszawa-Poznań: Wydawnictwo Naukowe PWN. 


\section{Aneks}

\section{Ankieta - Dotychczasowa praca ze słownictwem. Moja nauka słownictwa. I roku FG ......10/2010r.}

Zanim przejdziesz do wypetniania poniższej ankiety zastanów sie przez chwile, jak uczytés(taś) sie dotychczas nowych stówek. Cұy masz swoja ulubiona metode? Co robisz, gdy napotykasz. w trakcie nauki jakieś nieznane ci dotad stówko?

1. Uczę się niemieckiego od ............... lat. Znajomość innych języków:
a) jęz. angielski od ..... lat-poziom
b) jęz.
od ..... lat - poziom
c) jęz.
od ..... lat - poziom
d)

2. Gdzie uczyłeś/uczyłaś się do tej pory języka niemieckiego (można zakreślić dowolną ilość punktów)
a) w szkole
b) na kursach języka niemieckiego
c) na korepetycjach
d) uczęszczałem na kółko języka niemieckiego
e) mieszkałem/mieszkałam jakiś czas w Niemczech
f) podczas wyjazdu do Niemiec lub innych krajów niemieckojęzycznych
g) inne

3. Jak ocenisz systematyczność swojej dotychczasowej nauki języka obcego w domu? Uczyłam/uczyłem się:
a) po każdej lekcji.
b) raz w tyg.
c) kilka razy w miesiącu
d) tylko przed sprawdzianem
e) inne

4. Jak oceniasz skuteczność swojej dotychczasowej nauki słownictwa
a) bardzo wysoko
b) wysoko
c) tak sobie
d) nisko
e) bardzo nisko

Wstaw krzyżyk w odpowiedniej rubryce:

\section{JAK (W JAKIEJ POSTACI) UCZYSZ SIĘ NOWYCH SŁÓWEK?}

\begin{tabular}{|l|l|l|l|l|l|}
\hline Częstotliwość & $\begin{array}{l}\text { Zawsze } \\
\text { b. często }\end{array}$ & często & czasami & rzadko & nigdy \\
\hline 1. Uczę się pojedynczych słówek. & & & & & \\
\hline 2. Uczę się rzeczowników wraz z ich rodzajnikiem. & & & & & \\
\hline $\begin{array}{l}\text { 3. Przy nauce nowego rzeczownika od razu uczę się } \\
\text { liczby mnogiej }\end{array}$ & & & & & \\
\hline $\begin{array}{l}\text { 4. Przy nauce rzeczownika uczę się czasownika, } \\
\text { z którym można połączyć dany rzeczownik }\end{array}$ & & & & & \\
\hline
\end{tabular}




\begin{tabular}{|l|l|l|l|l|l|}
\hline 5. Uczę się poszczególnych fraz, wyrażeń jako całości. & & & & & \\
\hline 6. Przy nauce czasownika & & & & & \\
\hline a) uczę się tylko bezokolicznika & & & & & \\
\hline $\begin{array}{c}\text { b) myślę również, jak odmienił(a)bym ten czasownik } \\
\text { w czasie teraźniejszym }\end{array}$ & & & & & \\
\hline c) uczę się od razu form podstawowych tego czasownika & & & & & \\
\hline 7. Uczę się części zdań lub całych zdań na pamięć. & & & & & \\
\hline
\end{tabular}

8. Inne

\section{JAK PRÓBUJESZ ZAPAMIĘTAĆ NOWO POZNANE SŁÓWKO?}

\begin{tabular}{|l|l|l|l|l|l|}
\hline $\begin{array}{l}\text { Częstotliwość } \\
\begin{array}{l}\text { 1. Uczę się nowych słówek powtarzając je w myśli kilkakrot- } \\
\text { nie. }\end{array}\end{array}$ & Często & czasami & rzadko & nigdy \\
\hline $\begin{array}{l}\text { 2. Uczę się nowych słówek powtarzając je głośno killkakrot- } \\
\text { nie. }\end{array}$ & & & & & \\
\hline $\begin{array}{l}\text { 3. Zapisuję sobie dane słówko kilkakrotnie } \\
\text { 4. Założyłem sobie katalog słówek. }\end{array}$ & & & & & \\
\hline $\begin{array}{l}\text { 5. Tłumaczę sobie zdania z danych słówkiem } \\
\text { 6. Próbuję skojarzyć nowe słówko z innymi znanymi mi już } \\
\text { słowami z danego języka }\end{array}$ & & & & & \\
\hline $\begin{array}{l}\text { 7. Próbuję skojarzyć nowe słówko z innymi znanymi mi już } \\
\text { słowami z innych języków, które znam lepiej. }\end{array}$ & & & & & \\
\hline $\begin{array}{l}\text { 8. Przyporządkowuję nowe słownictwo określonym dziedzi- } \\
\text { nom i wyrazom pochodnym lub pokrewnym. }\end{array}$ & & & & & \\
\hline 9. Próbuję sam utworzyć zdania z nowym słówkiem & & & & & \\
\hline 10. Porządkuję moje słownictwo & & & & & \\
\hline
\end{tabular}

11. Inne

12. Moja najbardziej ulubiona metoda przyswojenia i zapamiętania słówka to:

\section{JAK ZACHOWUJESZ SIĘ, GDY NAPOTKASZ NA NIEZNANE TOBIE SŁÓWKO W CZYTANYM PRZEZ CIEBIE TEKŚCIE?}

\begin{tabular}{|l|l|l|l|l|l|}
\hline $\begin{array}{l}\text { Częstotliwość } \\
\text { 1. Sprawdzam znaczenia wszystkich nieznanych mi słówek w słow- } \\
\text { niku }\end{array}$ & zawsze & często & czasami & rzadko & nigdy \\
\hline $\begin{array}{l}\text { 2. Wypisuję nad niemieckim słówkiem tylko jego znaczenie po } \\
\text { polsku }\end{array}$ & & & & & \\
\hline $\begin{array}{l}\text { 3. Wypisuję ze słownika do zeszytu nieznane mi niemieckie słówka } \\
\text { wraz z ich polskim odpowiednikiem }\end{array}$ & & & & & \\
\hline $\begin{array}{l}\text { 4. Szukając danego słowa w słowniku wypisuję sobie również wyrazy } \\
\text { pokrewne. }\end{array}$ & & & & & \\
\hline $\begin{array}{l}\text { 5. Szukając jakiegoś słowa wypisuję ciekawe zwroty i wyrażenia z } \\
\text { danym słówkiem }\end{array}$ & & & & \\
\hline
\end{tabular}


Słabo rozwinięta kompetencja leksykalna dorosłych - przyczyny, skutki i możliwości...

\begin{tabular}{|l|l|l|l|l|l|}
\hline $\begin{array}{l}\text { 6. Czytając teksty lub zdania, w których występują nieznane mi } \\
\text { słówka, próbuję odgadnać ich znaczenie z kontekstu. }\end{array}$ & & & & & \\
\hline 7. Pracuję ze słownikiem dwujęzycznym & & & & & \\
\hline 8. Pracuję ze słownikiem jednojęzycznym & & & & & \\
\hline $\begin{array}{l}\text { 9. Analizuję nowe słówko i szukam w nim znanych mi leksemów, } \\
\text { czyli sylab, które niosą ze soba jakieś znaczenie. }\end{array}$ & & & & & \\
\hline $\begin{array}{l}\text { 10. Szukam reguł - patrzę na końcówkę, żeby stwierdzić, jaka część } \\
\text { mowy (czy jest to przymiotnik, czasownik itd.) }\end{array}$ & & & & & \\
\hline $\begin{array}{l}\text { 11. Sam próbuję odgadnać znaczenie nieznanego słowa, dopiero } \\
\text { potem pytam nauczyciela. }\end{array}$ & & & & & \\
\hline $\begin{array}{l}\text { 12. Sam próbuję odgadnać znaczenie nieznanego słowa, dopiero } \\
\text { potem sam szukam znaczenia w słowniku. }\end{array}$ & & & & \\
\hline
\end{tabular}

13. Moje najczęstsze zachowanie w takim przypadku to: 